\title{
An Evaluation of the Tolerant to Higher Inflation Rate in the Short Run by the Brazilian Central Bank in the Period 2001-2012*
}

\author{
Tito Belchior Silva Moreira ${ }^{\dagger}$, Geraldo da Silva e Souza ${ }^{\ddagger}$, Roberto \\ Ellery Jr ${ }^{\S}$
}

\begin{abstract}
Contents: 1. Introdução; 2. Methodological Aspects; 3. Empirical Results; 4. Conclusions; A. ANNEX 1: Aditional Empirical Results; B. ANNEX 2: Data Description.

Keywords: Taylor Rule, Inflation Rate in the Short Run, Monetary Policy, Inflation Targeting.

JEL Code: $\quad$ E31; E52; E58.
\end{abstract}

This article investigates the degree of tolerance to higher inflation rates in the short run by the presidents of the Brazilian Central Bank in the period 2001-2012. We used monthly data and various specifications and estimates of the Taylor rule via GMM. In general, the results show the following empirical evidences: i) the mandate of Henrique Meirelles was less tolerant to higher inflation rates when comparing with the mandate of Armínio Fraga and ii) the Alexandre Tombini's administration is more tolerant to higher inflation rate in the short run than Armínio Fraga's.

Este artigo analisa o grau de tolerância a elevadas taxas de inflação de curto prazo pelos presidentes do Banco Central no período de 2001 a 2012. Foram usados dados mensais e várias especificações e estimativas da regra de Taylor via GMM. Em geral, os resultados mostram as seguintes evidências empíricas: i) o mandato de Henrique Meirelles foi menos tolerante a taxas de inflação mais elevadas do que o mandato de Armínio Fraga e ii) a administração de Alexandre Tombini é mais tolerante a taxas de inflação mais elevadas no curto prazo do que a de Armínio Fraga.

\footnotetext{
* The authors would like to thank the CNPq (Conselho Nacional de Pesquisa - the National Research Council) for its financial support. An expanded version of this article in the form of a working paper is available on the site of SSRN (papers.ssrn.com).

†Universidade Católica de Brasília, Campus Avançado Asa Norte - SGAN 916, Módulo B, Departamento de Economia, Avenida W5 - CEP: 70.790-160 - Brasília/DF E-mail: tito@pos .ucb.br

‡Embrapa, Av. W3 Norte (final) - Edifício Sede - Asa Norte - Brasília/DF, Secretaria de Gestão Estratégica SGE. E-mail: geraldo . souza@embrapa.br

$\S$ Universidade de Brasília, Campus Darcy Ribeiro - Prédio da FACE - Departamento de Economia - Asa Norte - Brasília/DF. E-mail: ellery@unb.br
} 


\section{INTRODUÇÃO}

The economic literature relative to higher inflation rates is very disperse and lacks relevant studies, despite its undeniable importance. Not much is known about the mechanisms by which higher inflation process occurs. In this context, the purpose of this paper is to investigate on a systematic way this process in Brazil, comparing the coefficients of elasticity of the monetary authority's reaction to changes in the Selic rate for a given increase in the inflation rate.

More specifically, this article aims to assess the degree of tolerance to the inflation rate in the short run by comparing the performances of the presidents of the Bacen in the period 2001-2012. The comment below, taken from the minutes of the 156th meeting held on 18 and 19/01/2012, and also present in several other minutes of the Monetary Policy Committee, inspired this paper.

"The committee also understands that low risks for the underlying inflation in the short run tend to reduce uncertainties regarding the future behavior of headline inflation, facilitate the assessment of scenarios by the monetary authority, as well as help the process of coordination of economic agents' expectations, mainly price setters'. It is additionally noteworthy that low risks for the underlying inflation in the short run tend to reinforce the effects of monetary policy actions, enabling them to affect in a more long-lasting manner the dynamics of headline inflation in the future. Although the Copom recognizes that other actions of macroeconomic policy may influence the price trajectory, it reaffirms its view that it the responsibility of the monetary policy to remain especially vigilant to guarantee that pressures detected in shorter horizons do not spread to longer horizons."

In this context, we use different specifications of the Taylor rule to evaluate this issue. Since the publication of the monetary policy rule proposed by TAYLOR (1993), several theoretical and empirical studies have been conducted following his approach. TAYLOR (1993) suggests that the process of implementation of a monetary policy can be modeled by a feedback rule, which we write as

$$
R_{t}=\beta_{0}+\beta_{1}\left(\pi_{t-1}-\pi^{*}\right)+\beta_{2} \tilde{y}_{t}
$$

where $\beta_{0}=\pi_{t-1}+\bar{r} ; R_{t}$ is the quarter $\mathrm{t}$ value of an interest rate instrument; $\pi_{t-1}$ is the average inflation rate over the four quarters prior to t; $\pi^{*}$ is the target inflation rate; $\tilde{y}_{t}=y_{t}-\bar{y}_{t}$ is the difference between the (logs) real GDP $y_{t}$ and its capacity or natural rate value $\bar{y}_{t}$ and $\bar{r}$ the real interest rate of equilibrium. The policy feedback parameters $\beta_{1}$ and $\beta_{2}$ are positive, such as each of them equals 0.5 in Taylor's (1993) example. Hence, the interest rate instrument is raised in response to values of inflation and output that are high relative to their targets.

CLARIDA et al. (1999) proposed a major modification in the rule proposed by TAYLOR (1993) with the introduction of a smoothing term, an auto-regressive component that captures the relationship between the interest rate and its lagged values, i.e.,

$$
R_{t}=\beta_{0}+\beta_{1} R_{t-1}+\beta_{2}\left(\pi_{t+1}^{e}-\pi^{*}\right)+\beta_{3} \tilde{y}_{t+1}^{e}
$$

where the parameter $\beta_{1}$ represents the degree of interest rate smoothing. In this sense, the higher the value of $\beta_{1}$, the greater the inertia in the dynamics of the interest rates, which means a higher serial correlation in the series.

The difference between the above two equations is that the rule of Equation 2 is the type forwardlooking while the Taylor rule (1993) is the type backward-looking (Equation 1). Equation 2 shows that the interest rate increases in response to an increase in inflation expectations $\left(\pi_{t+1}^{e}\right)$ in relation to a target and an increase in the expected output gap $\left(y_{t+1}^{e}\right)$ Equation 2 explicitly highlights the importance of lags in monetary policy, which requires of the Central Bank a prospective behavior.

TAYLOR (1999) presents a collection of articles referring to this literature. His striking findings relates to the potential response of interest rates to an array of variables, including changes in the rates of inflation, unemployment, and exchange. He points out that simple policy rules are more robust and more efficient than complex rules with multiple variables. 
The Brazilian literature is reach. We highlight here a number of studies that estimate rules à la Taylor. These are ANDRADE and DIVINO (2001), MENDONÇA (2001), FIGUEIREDO and FERREIRA (2002), MINELLA et al. (2002), FAVERO and GIAVAZZI (2002), MINELLA et al. (2003), SALGADO et al. (2005), MENDONÇA (2007), MOREIRA et al. (2007), MODENESI (2011) and MOREIRA (2011).

ROMER and ROMER (2002) make an interesting study on the implementation of U.S. monetary policy to the various mandates of the presidents of the FED based on the evaluation of the minutes of the Monetary Policy Committee (FOMC). The authors make comments about the FOMC minutes for the mid- and late $1950 \mathrm{~s}$. Based on the analysis of FED records, the authors show that policymakers had a definite aversion to inflation and were willing to accept significant costs to prevent it from rising to even moderate levels. They stress that this aversion to inflation was the result of policymaker's beliefs that higher inflation could not raise output in the long run, that the level of output that would trigger increases in inflation was only moderate, and that inflation had large real costs in the medium and long runs.

Empirical estimates of a forward-looking Taylor rule show that policymakers in the 1950s raised nominal interest rates more than one-for-one with increases in expected inflation. Furthermore, ROMER and ROMER (2002) suggest that monetary policy in the 1950s was more similar to policy in the 1980s and 1990s than to that in the late 1960s and 1970s. The particular specification that ROMER and ROMER (2002) consider is a forward-looking Taylor rule, base on CLARIDA et al. (2000) where

$$
R_{t}=\beta_{0}+\beta_{1} \pi_{t+1}^{e}+\beta_{2} \tilde{y}_{t+1}^{e}
$$

In this sense our article is motivated by the work of ROMER and ROMER $(2002,2004) .{ }^{1}$

Our article proceeds as follows. We cover the methodological aspects in Section 2. The empirical results are presented in Section 3. In Section 4 we present the main conclusions. In Annex 1 we show further empirical results that support the findings of Section 3 and we define the variables used in the analysis in Annex 2.

\section{METHODOLOGICAL ASPECTS}

In our empirical work, we use monthly data from 2001:01 to 2012:12. The variables and the notation used in this article (in parentheses) are as follow. Real GDP $(Y)$ is computed deflating GDP by the General Price Index (IGP-DI). ${ }^{2}$ As a proxy for real output gap $(y)$, we compute the difference between real GDP and the same series smoothed by the Hodrick-Prescoter filter. If the difference between real GDP and potential GDP (trend) is positive, the value indicates excess demand. Likewise we compute the expected output gap $\left(y^{e}\right)$. We use the consumer confidence index as a proxy for real expected output. ${ }^{3}$. We consider the primary budget surplus/GDP (PBS/GDP) ratio as the relevant fiscal variable. ${ }^{4}$ Finally we use the stock of money M1 deflated by IPCA (Consumer Price Index) to represent the demand for money. All these variables are considered in natural logs.

The inflation rate $(\pi)$ is measured by the percentage variation of IPCA. This is the Brazilian consumer price index used by the Brazilian Central Bank to target inflation. We use the percentage variation of expected Brazilian consumer price index as a proxy for expected inflation $\left(\pi^{e}\right)$. The nominal interest

\footnotetext{
${ }^{1}$ Recently, ROMER and ROMER (2013) conjecture based on the records of the US monetary policies in the 1930s, 1970s, and 20072012, that overly pessimistic views about the power of the monetary policy have been a critical source of failures of monetary policies over the past century. This paper has useful information to all who are interested in Federal Reserve history, but also to those seeking an interesting perspective on recent monetary policy.

${ }^{2}$ We follow the same procedure of MOREIRA and SOARES (2012) and ARAÚJO and DONHA (2011).

${ }^{3}$ The Central Bank uses this index in the analysis of the minutes of COPOM as indicative of consumer optimism that is a proxy for demand variation. Consumers more optimistic tend to demand more goods and services.

${ }^{4}$ The Central Bank also uses this fiscal indicator in the analysis of the minutes of COPOM.
} 
rate $(R)$ is the SELIC interest rate. The SELIC rate is the benchmark interest rate, a base rate influencing the level of all other interest rates in the Brazilian economy.

The percentage variation of effective real exchange index $(e)$ is a proxy for the real exchange rate. The real interest rate $(r)$ is the SELIC base interest rate minus the expected inflation. The deviation between inflation rate and the expected inflation rate $\left(\pi-\pi^{e}\right)$ is taken into account to determine the SELIC base interest rate. The percentage variation of the nominal exchange index $(\eta)$ is a proxy for the nominal exchange rate. All these variables are in percentage variation. Table 6 in the Annex 2 shows the description of aggregate variables.

We use dummies variables (D) to identify the presidents of the Brazilian Central Bank. In this sense, $\mathrm{DAF}=1$ if the president is Armínio Fraga Neto (2001:01 to 2002:12), otherwise DAF =0; DHM = 1 if the president is Henrique de Campos Meirelles (2003:01 to 2010:12), otherwise DHM $=0$ and DAT $=1$ if the president is Alexandre Tombini (2011:01 to 2012:12), otherwise DAT $=0 .^{5}$

The time-series models are presented in detail in Section 3. We use simultaneous equation models and generalized method of moments (GMM) with instrumental variables. It should be noted that use of the GMM is appropriate when the regressors and the error term are correlated, in which case instrumental variables should be used which are not correlated with the residuals, but are correlated with the regressors. We use over-identifying restrictions and the $J$-statistic to assess model fitting. The null-hypothesis is that the over-identification constraints are satisfied. The instruments are also used to resolve endogeneity problems.

Furthermore, when the variables are not stationary specific problems are known to arise in conventional inference procedures based on ordinary last squares (OLS) regressions. JOHNSTON and DINARDO (p. 317 1997) stress the importance of knowing whether similar problems occur in the context of twostage least squares regressions.

HSIAO (1997b,a) analyse this problem and conclude that inference with two-stage last square estimators using instrumental variables remains valid, even in the case of non-stationary or non-cointegrated series. In that context, Hsiao's conclusions also hold when GMM is applied.

The GMM method applied to estimate the parameters present in the three simultaneous systems below, produces the results shown in the the next sections. For the the first system we estimate the IS Curve (Equation 4) as

$$
y_{t}=\beta_{0}+\beta_{1} y_{t-j}+\beta_{2} y_{t-j}^{e}+\beta_{3} r_{t-j}+\beta_{4}(p s b / g d p)_{t-j}+\beta_{5} e_{t-j}+u_{t}
$$

where $j=0,1,2,3 \ldots$ months.

The Taylor rule (Equation 5) is

$$
\begin{aligned}
R_{t} & =\beta_{0}+\beta_{1} R_{t-j}+\beta_{2} \pi_{t-j}^{e}+\beta_{3} y_{t-j}+\beta_{4} \pi_{t-j}^{e}{ }^{*} D H M+\beta_{5} \pi_{t-j}^{e}{ }^{*} D A T+\beta_{6} D H M \\
& +\beta_{7} D A T+\beta_{8}\left(\pi_{t-j}-\pi_{t-j}^{e}\right)+\nu_{t}
\end{aligned}
$$

In this equation notice the interactions between the expected inflation rate and the dummies for the period of Henrique Meirelles $\left(\pi_{t}^{e *} D H M\right)$ and for the period of Alexandre Tombini $\left(\pi_{t}^{e *} D A T\right)$ as well as the effect of the expected inflation rate $\left(\pi_{t}^{e}\right)$ on the nominal interest rate (SELIC). The corresponding parameters allow the comparison of the inflation aversion revealed by the Henrique Meirelles and by the Alexandre Tombini administrations with the Armínio Fraga's administration.

For the second system the Phillips curve ${ }^{6}$ is

\footnotetext{
${ }^{5}$ Arminio Fraga was president of the Central Banks since April/1999. However, the series about expected inflation is available only since 2001. In this context, our empirical series begin just in 2001.

${ }^{6}$ SACHSIDA and MENDONÇA (2009), SCHETTINI et al. (2012), SACHSIDA et al. (2011), MENDONCA et al. (2012), SACHSIDA et al. (2009) estimate several different specifications of the Phillips to the Brazilian economy.
} 


$$
\pi_{t}=\beta_{0}+\beta_{1} \pi_{t-j}+\beta_{2} \pi_{t-j}^{e}+\beta_{3} y_{t-j}+\beta_{4} \eta_{t-j}+u_{t}
$$

where $j=0,1,2,3 \cdots$ months, and the Taylor rule (Equation 7 ) is

$$
\begin{aligned}
R_{t} & =\beta_{0} \pi_{t-j}+\beta_{1} R_{t-j}+\beta_{2} \pi_{t-j}^{e}+\beta_{3} y_{t-j}+\beta_{4} \pi_{t-j}^{e}{ }^{*} D H M+\beta_{5} \pi_{t-j}^{e}{ }^{*} D A T+\beta_{6} D A T \\
& +\beta_{7} D H M+\beta_{8}\left(\pi_{t-j}-\pi_{t-j}^{e}\right)+\beta_{9}+\nu_{t}
\end{aligned}
$$

The third system shows the Taylor rule as Equation $8^{7}$

$$
\begin{aligned}
R_{t} & =\beta_{0}+\beta_{1} R_{t-j}+\beta_{2} \pi_{t-j}^{e}+\beta_{3} y_{t-j}+\beta_{4} \pi_{t-j}^{e}{ }^{*} D H M+\beta_{5} \pi_{t-j}^{e}{ }^{*} D A T+\beta_{6} D A T \\
& +\beta_{7} D H M+\beta_{8}\left(\pi_{t-j}-\pi_{t-j}^{e}\right)+\beta_{9} R_{t-j}+\nu_{t}
\end{aligned}
$$

where $j=0,1,2,3 \cdots$ months, and the demand for money is given by equation 9 as follows

$$
(M 1 / P)_{t}=\beta_{0}+\beta_{1} R_{t-j}+\beta_{2} Y_{t-j}+\nu_{t}
$$

In the Annex 1 we estimate two more systems to check the consistency of the empirical results. ${ }^{8}$ In total we estimate five different systems to address the objective of this paper.

\section{EMPIRICAL RESULTS}

This section presents the empirical results resulting from simultaneous equation models estimated via generalized method of moments (GMM) with instrumental variables. Notice that for each system the specification of the Taylor's rule is different.

\subsection{IS curve and a Taylor rule}

The estimation of the IS curve and of the Taylor rule are in Table 1. The results shown in Model 1 indicate that all variables are statistically significant at the $1 \%$ level. All coefficients have the expected signs. The value of the $J$-statistic at 0.2029 , with a $p$-value of 0.90 , does not indicate evidence to reject the model specification.

The empirical results presented in Model 1 show that for every 1\% increase in Output Gap $\left(y_{t-1}\right)$ and in the Consumer Confidence Index (proxy to expected output gap, $y_{t-1}^{e}$ ) lagged by one month, the current Output Gap rises by $0.7671 \%$ and $0.0284 \%$ respectively, ceteris paribus. Furthermore, the positive parameter for the change in the real exchange rate $\left(e_{t}\right)$ implies domestic currency depreciation. Although the real exchange rate show a positive association with the Output Gap as expected, the estimated coefficient value is near zero.

The Output Gap is negatively affected by the monetary and fiscal policies with a lag of three months. In this sense, a $1 \%$ quarterly decrease in the real interest rate $\left(r_{t-3}\right)$ and in the primary surplus/GDP ratio $(p s b / g d p)_{t-3}$ will increase the Output Gap by $0.5473 \%$ and $0.3830 \%$ respectively, ceteris paribus. However, we can analyze the indirect effects of real interest rate and of primary surplus/GDP ratio on nominal interest rate $\left(R_{t}\right)$, considering the results presented in Model 2. In this context, given that a $1 \%$ increase in output gap increases nominal interest rate by $0.8778 \%$, then the final effect of a $1 \%$

\footnotetext{
${ }^{7}$ Notice that the specifications of the Taylor rule (Equations 5, 7, and 8) follow CLARIDA et al. (2000) and ROMER and ROMER (2002). In this sense, they are similar, but not identical, to the specifications given in Equation 3 since the nominal interest rate responds to the expected inflation rate.

${ }^{8}$ The specifications of the Taylor rule presented in the annexes follow TAYLOR (1993). In this sense, they are similar, but not identical, to the specification given in Equation 1.
} 
decrease in the real interest rate and in the primary surplus/GDP ratio will cause a positive impact of $0.4804 \%$ and $0.3362 \%$ quarterly decrease in the SELIC $\left(R_{t}\right)$ respectively, ceteris paribus.

We use three variables to study to compare the aversion to inflation revealed by Henrique Meirelles' administration and by the Alexandre Tombini's administration with relation to Armínio Fraga's administration. These are interaction between the expected inflation rate and dummies for the period of Henrique Meirelles ( $\left.\pi_{t}^{e}{ }^{*} \mathrm{DHM}\right)$ and for the period of Alexandre Tombini ( $\left.\pi_{t}^{e}{ }^{*} \mathrm{DAT}\right)$ and the effect of the expected inflation rate $\left(\pi_{t}^{e}\right)$ on the nominal interest rate (SELIC). The empirical results of the Taylor rule are shown in Model 2 where all estimated coefficients are statistically significant at $5 \%$ level, except the coefficients of the constant term, $D H M$ and $\pi_{t}^{e *} D H M$.

Table 1: Simultaneous Equations Models

Estimation Method: GMM (Kernel: Bartlett, Bandwidth, Fixed)

\begin{tabular}{|c|c|c|c|}
\hline \multicolumn{2}{|c|}{ Model 1: IS curve } & \multicolumn{2}{|c|}{ Model 2: Taylor rule } \\
\hline Variables & Coefficient (S.E.) & Variables & Coefficient (S.E.) \\
\hline Constant & $0.0124(0.0012)^{*}$ & Constant & $0.0310(0.0206)$ \\
\hline$y_{t-1}$ & $0.7671(0.0211)^{*}$ & $R_{t-1}$ & $0.9110(0.0044)^{*}$ \\
\hline$y_{t-1}^{e}$ & $0.0284(0.0107)^{*}$ & $\pi_{t}^{e}$ & $0.1550(0.0334) *$ \\
\hline$r_{t-3}$ & $-0.5473(0.1115)^{*}$ & $y_{t}$ & $0.8778(0.0355)^{*}$ \\
\hline$(p s b / g d p)_{t-3}$ & $-0.3830(0.0175)^{*}$ & $\pi_{t}^{e *} D H M$ & $0.0163(0.0325)$ \\
\hline$e_{t}$ & 5.07E-06 (1.13E-0.6) * & $\pi_{t}^{e *} D A T$ & $-0.2385(0.0458)^{*}$ \\
\hline & & $D H M$ & $-0.0155(0.0206)^{* *}$ \\
\hline & & $D A T$ & $0.0738(0.0234)^{*}$ \\
\hline & & $\left(\pi_{t}-\pi_{t}^{e}\right)$ & $0.0133(0.0048)^{*}$ \\
\hline $\mathrm{R}^{2}$ & $44.40 \%$ & $\mathrm{R}^{2}$ & $88.90 \%$ \\
\hline$J$-statistic & 0.2029 & $J$-statistic & 0.2029 \\
\hline \multicolumn{4}{|c|}{$\begin{array}{l}p s b / g d p(-4 \text { to }-9) ; e(-4 \text { to }-9) ; R(-4 \text { to }-9) ; \pi^{e}(-4 \text { to }-9) ; \\
\pi-\pi^{e}(-4 \text { to }-9) ; E M B I(-4 \text { to }-9), \text { C. }\end{array}$} \\
\hline
\end{tabular}

Source: Prepared by authors. Note : ${ }^{*} p$-value $\leq 0.01 ;{ }^{* *} p$-value $\leq 0.05 ;{ }^{* * *} p$-value $\leq 0.10$;

$(\mathrm{SE})=$ Standard Error.

The estimated coefficient of the lagged monthly interest rate $\left(R_{t-1}\right)$ is 0.911 and it shows an inertial effect of the interest rate. As expected, the signs of the estimated coefficients of $\pi_{t}^{e}$ and $y_{t}$ are positive with values of 0.1550 and 0.8778 respectively. The deviation between inflation rate and expected inflation rate $\left(\pi-\pi^{e}\right)$ presents an estimated coefficient positive value of 0.0133 . It shows that an increase of $1 \%$ in this deviation will increase the SELIC by $0.0133 \%$. This result means that if the economics agents estimate a expected inflation rate lower than the actual inflation rate systematically, the Central Bank will incorporate in their Taylor rule this deviation and will respond to this error level with an increase in the nominal interest rate.

As the estimated coefficient of dummy variable "DHM" is not statistically different of zero, then the intercept associated with the Henrique Meirelles' administration is not statistically different from the Armínio Fraga's. The interaction variable " $\pi_{t}^{e *} D H M$ " is not statistically different from the Armínio 
Fraga's administration as well. These results show that the aversion to inflation rate in the short run of both administrations is similar.

On the other hand, the estimated coefficient of the dummy variable "DAT" is statistically different from the Armínio Fraga's administration effect and the interaction variable " $\pi_{t}^{e *} D A T$ " is also statistically different from the Armínio Fraga's administration. The estimated coefficient value of the interaction variable " $\pi_{t}^{e *} D A T$ " is -0.2385 . Therefore, the estimated coefficient value that shows the aversion to inflation rate in the short run regarding to Alexandre Tombini's administration is $(0.1550-0.2385)$ -0.0835 . This result shows that the Alexandre Tombini's administration is more tolerant to the short run inflation rate than Armínio Fraga's.

\subsection{Phillips curve and a Taylor rule}

The estimation of the Phillips curve and the Taylor rule are shown in Table 2. The results of Model 3 indicate that all variables are statistically significant at the $1 \%$ level. All coefficients have the expected signs. The value of the $J$-statistic at 0.2114 , with a $p$-value of 0.95 , and does not provide evidence to reject the model specification.

The empirical results shown in Model 3 show that the elasticities obtained by GMM for inflation rate lagged by one month $\left(\pi_{t-1}\right)$, expected inflation rate $\left(\pi_{t}^{e}\right)$, output gap $\left(y_{t}\right)$ and the nominal exchange rate $\left(\eta_{t}\right)$ are $0.5136,0.7433,0.8249$ and 0.0067 respectively.

Similarly, for the Taylor rule, the variables of concern are the interactions with the dummies for the period of Henrique Meirelles $\left(\pi_{t}^{e *} D H M\right)$ and for the period of Alexandre Tombini $\left(\pi_{t}^{e *} D A T\right)$ and the effect of the expected inflation rate $\left(\pi_{t}^{e}\right)$ on the nominal interest rate (SELIC). The empirical results of the Taylor rule are presented in Model 4 and all coefficients are statistically significant at the 5\% level, except the coefficients of the constant term, DHMand $\left(\pi_{t-1}-\pi_{t-1}^{e}\right)$. The estimated coefficient of $\left(\pi_{t}^{e *} D H M\right)$ is marginally significant at the $6 \%$ level.

The estimated coefficient of the lagged monthly interest rate $\left(R_{t-1}\right)$ is 0.9062 and it shows an inertial effect of the interest rate. As expected, the signs of estimated coefficients of $\pi_{t}^{e}$ and $y_{t}$ are positive with values of 0.1055 and 1.0435 respectively. Now, the estimated coefficient of the output gap is greater than one, while in Model 2 the estimated coefficient of this same variable is lower than one.

The indirect impact of the explanatory variables of the Phillips Curve on the Taylor rule occurs via $\pi_{t-1}$ and is positive, since estimated coefficient $\pi_{t-1}$ is 0.0556 . We observe that the real (IS curve) and the nominal (Phillips curve) exchange rates have low elasticities.

Comparing the results of the performance of the presidents of the Central Bank, we can see that there are differences. As the estimated coefficient of the dummy variable " $D H M^{\prime \prime}$ is not statistically different of zero, we conclude that the intercept for the Henrique Meirelles' administration is not statistically different from the Armínio Fraga's administration. However, the interaction variable " $\pi_{t}^{e *} D H M$ " is marginally significant at $6 \%$ level. This result shows that the aversion to the inflation rate in the short run of Henrique Meirelles is higher than that of the Arminio Fraga's administration. The estimated coefficient value of the interaction variable " $\pi_{t}^{e *} D H M$ " is 0.0329 . Therefore, the estimated coefficient value that shows the aversion to inflation rate in the short run regarding to Henrique Meirelles's administration is $(0.1055+0.0329)$ 0.1384. This result shows that the Henrique Meirelles' administration is less tolerant to the short run inflation rate that of Armínio Fraga's.

The results regarding to performance comparisons between the Armínio Fraga and Alexandre Tombini administration does not indicate change. The estimated coefficients of the dummy variable " $D A T$ " and the interaction variable " $\pi_{t}^{e *} D A T$ " are statistically different from zero. The estimated coefficient value of interactive variable $\pi_{t}^{e *} D A T$ is -0.2065 . Hence, the estimated coefficient value that shows the aversion to inflation rate in the short run regarding to the Alexandre Tombini's administration is $(0.1055-0.2065)-0.1010$. This result also shows that the Alexandre Tombini's administration is more tolerant to the short run inflation rate than Armínio Fraga's. 
Table 2: Simultaneous Equations Models.

Estimation Method: GMM (Kernel: Bartlett, Bandwidth, Fixed)

\begin{tabular}{|c|c|c|c|}
\hline \multicolumn{2}{|c|}{ Model 3: Phillips curve } & \multicolumn{2}{|c|}{ Model 4: Taylor rule } \\
\hline Variables & Coefficient (S.E.) & Variables & Coefficient (S.E.) \\
\hline Constant & $-0.0915(0.0075)^{*}$ & $\pi_{t-1}$ & $0.0556(0.0052) *$ \\
\hline$\pi_{t-1}$ & $0.5136(0.0051)^{*}$ & $R_{t-1}$ & $0.9062(0.0026) *$ \\
\hline$\pi_{t}^{e}$ & $0.7436(0.0153)^{*}$ & $\pi_{t}^{e}$ & $0.1055(0.0159)$ * \\
\hline$y_{t}$ & $0.8249(0.0663)^{*}$ & $y_{t}$ & $1.0435(0.0257)$ * \\
\hline$\eta_{t}$ & $0.0067(0.0004)^{*}$ & $\pi_{t}^{e *} D H M$ & $0.0329(0.0174)^{* *}$ \\
\hline & & $\pi_{t}^{e *} D A T$ & $-0.2065(0.0243) *$ \\
\hline & & $D A T$ & $0.0723(0.0119)^{*}$ \\
\hline & & $D H M$ & $-0.0083(0.0133)$ \\
\hline & & $\left(\pi_{t-1}-\pi_{t-1}^{e}\right)$ & $0.001713(0.0054)$ \\
\hline & & Constant & $0.0178(0.0111)$ \\
\hline $\mathrm{R}^{2}$ & $64.33 \%$ & $\mathrm{R}^{2}$ & $89.08 \%$ \\
\hline$J$-statistic & 0.2114 & $J$-statistic & 0.2114 \\
\hline
\end{tabular}

Instruments: $y(-4$ to -9$) ; y^{e}(-4$ to -9$) ; r(-4$ to -9$)$;

$\mathrm{psb} / \mathrm{gdp}(-4$ to -9$) ; e(-4$ to -9$) ; R(-4$ to -9$) ; \pi^{e}(-4$ to -9$)$;

$\pi-\pi^{e}(-4$ to -9$) ; E M B I(-4$ to -9$), \eta(-4$ to -9$)$, C.

Source: Prepared by authors. Note : ${ }^{*} p$-value $\leq 0.01 ;{ }^{* *} p$-value $\leq 0.05 ;{ }^{* * *} p$-value $\leq 0.10$; $(\mathrm{SE})=$ Standard Error. 


\subsection{Taylor rule and demand for money}

Estimation of the Taylor rule and the demand for money are in Table 3. The results shown in Model 5 indicate that all variables are statistically significant at the $1 \%$ level. The value of the $J$-statistic at 0.2115 , with a $p$-value of 0.99 , and does not provide evidence to reject the model specification.

The estimated coefficient of the lagged monthly interest rate $\left(R_{t-1}\right)$ is 0.4291 and and of the two lagged $\left(R_{t-2}\right)$ is 0.4972 . These results show inertial effect of the interest rate in both lags. Notice that this specification of Taylor rule is different from the ones presented in Models 2 and 4 . Here we introduced $R_{t-2}$ in the equation. The statiscal inference does not change. The Alexandre Tombini's administration is more tolerant to the inflation rate in the short run that Armínio Fraga's. The signs of the estimated coefficients of $\pi_{t}^{e}$ and $y_{t}$ are positive with values of 0.2212 and 0.7846 respectively. The deviation between the inflation rate and the expected inflation rate $\left(\pi-\pi^{e}\right)$ has a positive value of 0.0559 .

The estimated coefficients of the dummies variable " $D H M$ " and " $D A T$ " are positive and they are statistically different of zero and indicate that the intercepts of both administrations are different from Armínio Fraga's. The interaction variables " $\pi_{t}^{e *} D H M$ " and " $\pi_{t}^{e *} D A T^{\text {" }}$ are also statistically different from the Arminio Fraga's administration as well. These results show that the three administrations are different, with different intercepts and different slopes. In those aspects, the results are different from Models 2 and 4. However, as shown below, at least one aspect presented in this subsection does not change: the Alexandre Tombini administration is more tolerant to the short run inflation rate than Arminio Fraga's. The estimated coefficient of the interaction variable " $\pi_{t}^{e *} D A T$ " is -0.3740 . Hence, the estimated coefficient value that shows the aversion to the inflation rate in the short run regarding Alexandre Tombini's administration is $(0.2212-0.3740)-0.1528$. This result also shows that the Alexandre Tombini's administration is more tolerant to the inflation rate in the short run than Arminio Fraga's.

The estimated coefficient of the interaction variable " $\pi_{t}^{e *} D H M$ " is -0.0401 . Hence, the estimated coefficient that shows the aversion to the inflation rate in the short run regarding the Henrique Meirelles's administration is $(0.2212-0.0401) 0.1811$. This result shows that the Henrique Meirelles administration is less tolerant to the inflation rate in the short run than Armínio Fraga's.

The results shown in Model 6 indicate that all variables are statistically significant at the $1 \%$ level. All coefficients have the expected signs. The results show that a decrease of $1 \%$ in the nominal interest rate $\left(R_{t}\right)$ and an increase of $1 \%$ in the real output $\left(Y_{t}\right)$ will increase the demand for money by $0.1980 \%$ and for $1.1360 \%$ respectively, ${ }^{9}$ ceteris paribus. In summary, the empirical results presented in this subsection show that, generally, the Henrique Meirelles's administration is less tolerant to the short run inflation rate than Armínio Fraga's. The Alexandre Tombini's administration is more tolerant to the inflation rate in the short run than Armínio Fraga's.

We consider in the Annex 1 alternative specifications for the Taylor's rule, where the nominal interest rate and the deviation between the SELIC and this same series smoothed by the Hodrick-Prescoter filter reacts to the difference between the actual inflation rate and the target of inflation rate. The statistical results are consistent with previous formulations.

\section{CONCLUSIONS}

This paper investigate how tolerant are the administrations of the presidents of the Central Bank of Brazil from 2001 to 2012 . Based on monthly data, we found empirical evidence that the Henrique Meirelles's administration is less tolerant to the short run inflation rate than Armínio Fraga's in the

\footnotetext{
${ }^{9}$ If we introduce the term (M1/P)t-1 in the right side of the demand for money equation system of the Model 6, the general results do not change in terms of statistical significance, signs of estimated coefficients and in terms of elasticities higher or lower than 1 . The income elasticity in the demand for money equation decreases from 1.1360 to 0.4008 .
} 
Table 3: Simultaneous Equations Models

Estimation Method: GMM (Kernel: Bartlett, Bandwidth, Fixed)

\begin{tabular}{|c|c|c|c|}
\hline \multicolumn{2}{|c|}{ Model 5: Taylor rule } & \multicolumn{2}{|c|}{ Model 6: Demand for money } \\
\hline Variables & Coefficient (S.E.) & Variables & Coefficient (S.E.) \\
\hline Constant & $-0.0351(0.0076)^{*}$ & Constant & $-1.8722(0.0544)^{*}$ \\
\hline$R_{t-1}$ & $0.4291(0.0048)^{*}$ & $R_{t}$ & $-0.1980(0.0015)^{*}$ \\
\hline$\pi_{t}^{e}$ & $0.2212(0.0125)^{*}$ & $Y_{t}$ & $1.1360(0.0042) *$ \\
\hline$y_{t}$ & $0.7846(0.0152)^{*}$ & & \\
\hline$\pi_{t}^{e *} D H M$ & $-0.0401(0.0116)^{*}$ & & \\
\hline$\pi_{t}^{e *} D A T$ & $-0.3740(0.0186)^{*}$ & & \\
\hline$D A T$ & $0.1432(0.0097)^{*}$ & & \\
\hline$D H M$ & $0.0264(0.0080)^{*}$ & & \\
\hline$\left(\pi_{t-1}-\pi_{t-1}^{e}\right)$ & $0.0559(0.0027)^{*}$ & & \\
\hline$R_{t-2}$ & $0.4972(0.0044)^{*}$ & & \\
\hline $\mathrm{R}^{2}$ & $91.88 \%$ & $\mathrm{R}^{2}$ & 88.02 \\
\hline$J$-statistic & 0.2115 & $J$-statistic & 0.2159 \\
\hline
\end{tabular}

Instruments: $y(-4$ to -9$) ; y^{e}(-4$ to -9$) ; r(-4$ to -9$)$;

$\mathrm{psb} / \mathrm{gdp}(-4$ to -9$) ; e(-4$ to -9$) ; R(-4$ to -9$) ; \pi^{e}(-4$ to -9$)$;

$\pi-\pi^{e}(-4$ to -9$) ; E M B I(-4$ to -9$), M 1 / P(-4$ to -9$)$, c.

Source: Prepared by authors. Note : ${ }^{*} p$-value $\leq 0.01 ;{ }^{* *} p$-value $\leq 0.05 ;{ }^{* * *} p$-value $\leq 0.10$;

$(\mathrm{SE})=$ Standard Error. 
last two year of his administration. On the other hand, Alexandre Tombini in the first two years of his administration is more tolerant to the inflation rate in the short run than Armínio Fraga in the last two years of his administration.

We must take into account that Fraga introduced the inflation target regime in a context of high instability due to the recent currency crises at the end of the 1990 decade and the instability generated by the federal election of 2002. It should be expected that the administration of the Brazilian Central Bank would be getting better through time in terms of performance due to the learning by doing process. With more experience and more know-how, it should be expected that an independent Central Bank would achieve a better performance or at least do not get worse after successive mandates.

Returning to ROMER and ROMER (2013) it is important to emphasize their conclusion that being a good central banker appears to require a balance between humility and arrogance. They argue that hubris can induce central bankers to do great harm. A belief that monetary policy can achieve stable low inflation together with below-normal unemployment can lead to the pursuit of reckless policies that do considerable damage.

\section{BIBLIOGRAPHY}

ANDRADE, J. P. \& DIVINO, J. A. C. A. (2001). Optimal rules for monetary policy in Brasil. Texto para Discussão 806, IPEA.

ARAÚJO, E. \& DONHA, T. (2011). Discricionariedade na política monetária brasileira após o plano real: Um teste baseado na correlação de longo prazo entre inflação e produto. Revista Economia Contemporânea, 15(3):375-405.

BANCO CENTRAL BRASIL (2011). Dez anos de metas para a inflação no Brasil: 1999-2009.

CLARIDA, R., GALÍ, J., \& GERTLER, M. (1999). The science of monetary policy: A new Keynesian perspective. Journal of Economic Literature, 37:1661-1707.

CLARIDA, R., GALÍ, J., \& GERTLER, M. (2000). Monetary policy rules and macroeconomic stability: Evidence and some theory. The Quarterly Journal of Economics, 115:147-180.

FAVERO, C. \& GIAVAZZI, F. (2002). Why are Brazil's interests rates so high? Working paper 224, Università Bocconi, Innocenzo Gasparini Institute for Economic Research.

FIGUEIREDO, F. M. R. \& FERREIRA, T. P. (2002). Os preços administrados e a inflação no Brasil. In Trabalhos para Discussão, volume 59. Banco Central do Brasil.

HSIAO, C. (1997a). Cointegration and dynamic simultaneous equations models. Econometrica, 65:358398.

HSIAO, C. (1997b). Statistical properties of the two-stage last squares estimator under cointegration. The Review of Economic Studies, 64(3):647-670.

JOHNSTON, J. \& DINARDO, J. (1997). Econometric Methods. McGraw-Hill, New York.

MENDONÇA, H. F. (2001). Mecanismos de transmissão monetária e a determinação da taxa de juros: Uma aplicação da regra de Taylor ao caso brasileiro. Economia e Sociedade, 16:65-81.

MENDONÇA, H. F. (2007). Metas de inflação e taxa de juros no Brasil: Uma análise do efeito dos preços livres e administrados. Revista de Economia Política, 27:431-451.

MENDONCA, M. J. C., MEDRANO, L. A., \& SACHSIDA, A. (2012). Inflação versus desemprego: Novas evidências para o Brasil. Economia Aplicada, 16:475-500. 
MINELLA, A., FREITAS, P., GOLDFAJN, I., \& MUINHOS, M. (2002). Inflation targeting in Brazil: Lessons and challenges. Trabalhos para Discussão 53, Banco Central do Brasil.

MINELLA, A., FREITAS, P., GOLDFAJN, I., \& MUINHOS, M. (2003). Inflation targeting in Brazil: Constructing credibility under exchange rate volatility. Journal of International Money and Finance, 27:1015-104.

MODENESI, A. M. (2011). Conservadorismo e rigidez na política monetária: Uma estimativa da função de reação do BB. Revista de Economia Política, 31(3):415-434.

MOREIRA, T. B. S. (2011). Brazil: An empirical study on fiscal policy transmission. CEPAL REVIEW, 103:187-205.

MOREIRA, T. B. S. \& SOARES, F. A. R. (2012). Brazil: The international financial crisis and counter-cyclical policies. CEPAL Review, 106(106):169-181.

MOREIRA, T. B. S., SOUZA, G. d. S., \& ALMEIDA, C. L. (2007). The fiscal theory of the price level and the interaction of monetary and fiscal policies: The Brazilian case. Brazilian Reviews of Econometrics, 27(1):85-106.

ROMER, C. D. \& ROMER, D. H. (2002). A rehabilitation of monetary policy in the 1950 s. Working paper 8800, NBER, Cambridge. Available in www .nber.org/papers/w8800.

ROMER, C. D. \& ROMER, D. H. (2004). Choosing the federal reserve chair: Lessons from history. Journal of Economic Perspectives, 18(1):129-162.

ROMER, C. D. \& ROMER, D. H. (2013). The most dangerous idea in federal reserve history: Monetary policy doesn't matter. American Economic Review: Papers \& Proceedings, 103(3):55-60.

SACHSIDA, A., J., M. M., \& MEDRANO, L. A. (2011). Inflação, desemprego e choques cambiais: Novas evidências para o Brasil. Texto para Discussão 1661, IPEA.

SACHSIDA, A. \& MENDONÇA, M. J. (2009). Reexaminando a curva de Phillips brasileira com dados de seis regiões metropolitanas. Texto para Discussão 1430, IPEA, Brasília.

SACHSIDA, A., RIBEIRO, M., \& SANTOS, C. H. (2009). A curva de Phillips e a experiência brasileira. Texto para Discussão 1429, IPEA, Brasília.

SALGADO, M. J. S., GARCIA, M. G. P., \& MEDEIROS, M. C. (2005). Monetary policy during Brazil's real plan: Estimating the Central Bank's reaction function. Revista de Economia Política, 59:61-79.

SCHETTINI, B. P., GOUVEA, R. R., \& SACHSIDA, A. (2012). Inflação, desemprego, e choques cambiais: Estimativo VAR para a economia brasileira. Texto para Discussão 1694, IPEA, Brasília.

TAYLOR, J. B. (1993). Discretion versus policy rules in practice. In Carnegie-Rochester Conference Series on Public Policy, volume 39, pages 195-214.

TAYLOR, J. B. (1999). Monetary Policy Rules. Chicago University Press, Chicago. 


\section{A. ANNEX 1: ADITIONAL EMPIRICAL RESULTS}

We show estimation of an IS curve and of a Taylor rule in Table 4. The results shown in Model 7 are similar to results presented in Model 1 . All variables are statistically significant at the $1 \%$ level and also present the expected signs. The value of the $J$-statistic at 0.2101 , with a $p$-value of 0.85 , and does not provide evidence to reject the model specification.

The specification of the Taylor rule presented in the Model 8 is different of the Taylor rule presented in Models 2, 4 and 5. Now, the reaction function of the Central Bank (Taylor rule) shows the nominal interest rate (SELIC) reacting to the difference between the actual inflation rate $\left(\pi_{t}\right)$ and the target of inflation rate $\left(\pi_{t}^{*}\right)$, i.e., $\left(\pi_{t}-\pi_{t}^{*}\right)$, instead of reacting just to the expected inflation rate $\left(\pi_{t}^{e}\right)$ as presented in Models 2, 4 and $5 .^{10}$

Table A-1: Simultaneous Equations Models

Estimation Method: GMM (Kernel: Bartlett, Bandwidth, Fixed)

\begin{tabular}{|c|c|c|c|}
\hline \multicolumn{2}{|c|}{ Model 7: IS curve } & \multicolumn{2}{|c|}{ Model 8: Taylor rule } \\
\hline Variables & Coefficient (S.E.) & Variables & Coefficient (S.E.) \\
\hline Constant & $0.0127(0.0016)^{*}$ & $R_{t-1}$ & $0.4784(0.0151)^{*}$ \\
\hline$y_{t-1}$ & $0.7678(0.0163)^{*}$ & $\pi_{t}-\pi_{t}^{*}$ & $0.0513(0.0109)$ * \\
\hline$y_{t-1}^{e}$ & $0.0307(0.0094)^{*}$ & $y_{t}$ & $0.7457(0.0438)$ \\
\hline$r_{t-3}$ & $-0.5640(0.1454)^{*}$ & $\left(\pi_{t}-\pi_{t}^{*}\right)^{*} D H M$ & $0.0273(0.0110)^{* *}$ \\
\hline$(p s b / g d p)_{t-3}$ & $-0.3840(0.0215)^{*}$ & $\left(\pi_{t}-\pi_{t}^{*}\right)^{*} D A T$ & $-0.2549(0.0317)^{*}$ \\
\hline$e_{t}$ & 5.27E-06 (1.68E-06) * & $D A T$ & $0.1473(0.0148)^{*}$ \\
\hline & & $D H M$ & $0.0529(0.0155)$ * \\
\hline & & $\pi_{t-1}-\pi_{t-1}^{e}$ & $0.0926(0.0056)^{*}$ \\
\hline & & $R_{t-2}$ & $0.5014(0.0161)^{*}$ \\
\hline & & Constant & $-0.0666(0.0182)^{*}$ \\
\hline $\mathrm{R}^{2}$ & $44.33 \%$ & $\mathrm{R}^{2}$ & $90.88 \%$ \\
\hline$J$-statistic & 0.201 & $J$-statistic & 0.2101 \\
\hline \multicolumn{4}{|c|}{ Instruments: $y(-4$ to -9$) ; y^{e}(-4$ to -9$) ; r(-4$ to -9$)$; } \\
\hline \multicolumn{4}{|c|}{$p s b / g d p(-4$ to -9$) ; e(-4$ to -9$) ; R(-4$ to -9$) ; \pi^{e}(-4$ to -9$)$; } \\
\hline \multicolumn{4}{|c|}{$\pi-\pi^{e}(-4$ to -9$) ; E M B I(-4$ to -9$), \mathrm{C}$} \\
\hline
\end{tabular}

Source: Prepared by authors. Note : ${ }^{*} p$-value $\leq 0.01 ;{ }^{* *} p$-value $\leq 0.05 ;{ }^{* * *} p$-value $\leq 0.10$;

$(\mathrm{SE})=$ Standard Error

We analyze the impact of variables of interest $\left(\pi_{t}-\pi_{t}^{*}\right),\left(\pi_{t}-\pi_{t}^{*}\right)^{*} D H M$ and $\left(\pi_{t}-\pi_{t}^{*}\right)^{*} D A T$ on the nominal interest rate (SELIC) based on Model 8. The statistical results show that all the estimated coefficients significant at $5 \%$ level. The estimated coefficient value of the interaction variable $\left(\pi_{t}-\right.$ $\left.\pi_{t}^{*}\right)^{*} D A T$ is -0.2549 . Given that the value of estimated coefficient of $\left(\pi_{t}-\pi_{t}^{*}\right)$ is 0.0513 , then the estimated coefficient value that shows the aversion to the inflation rate in the short run regarding to Alexandre Tombini's administration is $(0.0513-0.2549)-0.2036$. This result also shows that the Alexandre Tombini's administration is more tolerant to the inflation rate in the short run than the Armínio Fraga's.

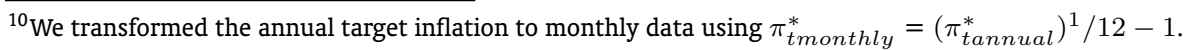


In the same context, the estimated coefficient value of the interaction variable $\left(\pi_{t}-\pi_{t}^{*}\right)^{*} D H M$ is 0.0273 . Hence, the estimated coefficient value that shows that the aversion to the inflation rate in the short run regarding to Henrique Meirelles administration is $(0.0513+0.0273) 0.0786$. This result shows that the Henrique Meirelles's administration is less tolerant to the inflation rate in the short run the Armínio Fraga's.

This section also presents empirical data based on simultaneous equation models via generalized method of moments (GMM) with instrumental variables. The estimation of an IS curve and another different specification of the Taylor rule is in Table 5. The results shown in Model 9 are similar to the results presented Model 7. All variables are statistically significant at the $1 \%$ level and show the expected signs. The value of the $J$-statistic at 0.2099 , with a $p$-value of 0.85 , does not provide evidence to reject the model specification.

Table A-2: Simultaneous Equations Models.

Estimation Method: GMM (Kernel: Bartlett, Bandwidth, Fixed)

\begin{tabular}{c|c|c|c}
\hline \multicolumn{2}{c|}{ Model 7: IS curve } & \multicolumn{2}{c|}{ Model 8: Taylor rule } \\
\hline Variables & Coefficient (S.E.) & Variables & Coefficient (S.E.) \\
\hline Constant & $0.0126(0.0016)^{*}$ & $\tilde{R}_{t-1}$ & $0.4455(0.0146)^{*}$ \\
$y_{t-1}$ & $0.7675(0.0159)^{*}$ & $\left(\pi_{t}-\pi_{t}^{*}\right)$ & $0.0486(0.0130)^{*}$ \\
$y_{t-1}^{e}$ & $0.0301(0.0093)^{*}$ & $y_{t}$ & $0.7059(0.0423)^{*}$ \\
$r_{t-3}$ & $-0.5647(0.1409)^{*}$ & $\left(\pi_{t}-\pi_{t}^{*}\right)^{*} D H M$ & $0.0171(0.0123)$ \\
$(p s b / g d p)_{t-3}$ & $-0.3829(0.0199)^{*}$ & $\left(\pi_{t}-\pi_{t}^{*}\right)^{*} D A T$ & $-0.2645(0.0309)^{*}$ \\
$e_{t}$ & $5.46 \mathrm{E}-06(1.78 \mathrm{E}-06)^{*}$ & $D A T$ & $0.1846(0.0139)^{*}$ \\
& & $D H M$ & $0.0849(0.0169)^{*}$ \\
& & $\pi_{t-1}-\pi_{t-1}^{e}$ & $0.0901(0.0062)^{*}$ \\
& & $\tilde{R}_{t-2}$ & $0.481845(0.0159)^{*}$ \\
& & Constant & $-0.1062(0.0160)^{*}$ \\
\hline $\mathrm{R}^{2}$ & $44.35 \%$ & $\mathrm{R}^{2}$ & $57.65 \%$ \\
\hline$J$-statistic & 0.2099 & $J$-statistic & 0.2099 \\
\hline
\end{tabular}

Instruments: $y(-4$ to -9$) ; y^{e}(-4$ to -9$) ; r(-4$ to -9$)$;

$\mathrm{psb} / \mathrm{gdp}(-4$ to -9$)$; $e(-4$ to -9$) ; R(-4$ to -9$) ; \pi^{e}(-4$ to -9$)$;

$\pi-\pi^{e}(-4$ to -9$) ; E M B I(-4$ to -9$)$, C.

Source: Prepared by authors. Note : ${ }^{*} p$-value $\leq 0.01 ;{ }^{* *} p$-value $\leq 0.05 ;{ }^{* * *} p$-value $\leq 0.10$;

$(\mathrm{SE})=$ Standard Error

The specification of the Taylor rule presented in the Model 10 is similar to the rule presented in the Model 8. There is just one difference. Now, the variable for the reaction function of Central Bank is not the nominal interest rate (SELIC), but the deviation between the SELIC $\left(R_{t}\right)$ and this same series smoothed by the Hodrick-Prescoter filter, $\left(R_{t}^{n}\right)$, that is $\tilde{R}_{t}=\left(R_{t}-R_{t}^{n}\right)$. We see that $\left(\tilde{R}_{t}\right)$ is a proxy for the nominal interest rate gap. If is positive, the authority monetary implements a contractionary monetary policy; otherwise, the Central Bank implements an expansionary monetary policy. We follow MOREIRA and SOARES (2012).

The empirical results of the Taylor rule presented in Model 10 show that all the estimated coefficients are statistically significant at the $5 \%$ level, except the coefficient of $\left(\pi_{t}-\pi_{t}^{*}\right)$. As the interaction 
variable is not statistically different from the Armínio Fraga's administration, this result indicates that the aversion to inflation in the short run for each administration is similar. The estimated coefficient value of the interaction variable is -0.2645 . Given that the value of the estimated coefficient of is 0.0486 , it follows that the estimated coefficient value that shows the aversion to the inflation rate in the short run regarding the Alexandre Tombini's administration is $(0.0486-0.2645)-0.2159$. Once again, this result shows that the Alexandre Tombini's administration is more tolerant to the inflation rate in the short run than Armínio Fraga's. 


\section{B. ANNEX 2: DATA DESCRIPTION}

Table B-3: Description of aggregate variables

\begin{tabular}{|c|c|c|c|c|}
\hline Variables & Acronym & Description of variable & Unit of measurement & Source \\
\hline General Price Index & IGP-DI & $\begin{array}{l}\text { General Price Index - Domestic } \\
\text { Supply }\end{array}$ & Index & IPEA \\
\hline GDP & GDP & GDP at market prices & $\mathrm{R} \$$ million & IPEA \\
\hline Real GDP & $Y$ & $\begin{array}{l}\text { GDP at market prices deflated } \\
\text { by general prices index - do- } \\
\text { mestic supply (IGP-DI) }\end{array}$ & $\mathrm{R} \$$ million & IPEA \\
\hline Consumer Confidence Index & $y^{e}$ & $\begin{array}{l}\text { Expectations Index (IEC) mea- } \\
\text { sures the rate of consumer con- } \\
\text { fidence in the Metropolitan Re- } \\
\text { gion of São Paulo }\end{array}$ & Index & $\begin{array}{l}\text { Federação do Comércio do Es- } \\
\text { tado de São Paulo }\end{array}$ \\
\hline Primary Budget Surplus & PBS & $\begin{array}{l}\text { NFSP - Federal Government and } \\
\text { Central Bank - primary - with- } \\
\text { out currency devaluation - R\$ } \\
\text { (million) }\end{array}$ & $\mathrm{R} \$$ million & IPEA \\
\hline Extended Consumer Price Index & IPCA & $\begin{array}{l}\text { The Broad Consumer Price In- } \\
\text { dex (IPCA) reported by the Na- } \\
\text { tional Bureau of Geography and } \\
\text { Statistics (IBGE) was chosen for } \\
\text { the purpose of gauging infla- } \\
\text { tion targets }\end{array}$ & Index & $\mathrm{BCB}$ \\
\hline Inflation rate & $\pi$ & $\begin{array}{l}\text { Inflation rate as measured by } \\
\text { the Extended Consumer Price } \\
\text { Index }\end{array}$ & Percentages & $\mathrm{BCB}$ \\
\hline Expected Inflation Rate & $\pi^{e}$ & $\begin{array}{l}\text { Expected rate of inflation based } \\
\text { on the IPCA earlier this month } \\
\text { to the end of the month. Me- } \\
\text { dian expectations of the Top } 5 \text { - } \\
\text { Short term }\end{array}$ & Percentages & $\mathrm{BCB}$ \\
\hline Target Inflation rate & $\pi^{*}$ & $\begin{array}{l}\text { The Brazilian Central Bank sets } \\
\text { inflation targets for each year } \\
\text { based on the IPCA }\end{array}$ & Percentages & $\mathrm{BCB}$ \\
\hline Nominal Interest Rate & $R$ & $\begin{array}{l}\text { Basic interest rate implemented } \\
\text { through the Special Settlement } \\
\text { and Custody System (SELIC) }\end{array}$ & Percentages & $\mathrm{BCB}$ \\
\hline Effective real exchange index & $e$ & $\begin{array}{l}\text { Exchange rate - real effective - } \\
\text { INPC - exports - index (average } \\
2005=100 \text { ) }\end{array}$ & Index & IPEA \\
\hline Nominal Interest Rate & $\eta$ & $\begin{array}{l}\mathrm{R} \$ / \mathrm{US} \$ \text { - commercial - average } \\
\text { price }\end{array}$ & Percentages & IPEA \\
\hline $\begin{array}{l}\text { JPMPBRA - JPM EMBI+ BRAZIL - } \\
\text { TOT RETURN IND }\end{array}$ & EMBI & $\begin{array}{l}\text { The Emerging Markets Bond In- } \\
\text { dex Plus (EMBI+) tracks total } \\
\text { returns for traded external debt } \\
\text { instruments (external meaning } \\
\text { foreign currency denominated } \\
\text { fixed income) in the emerging } \\
\text { markets }\end{array}$ & Index & Morgan Markets \\
\hline
\end{tabular}

Source: Prepared by the authors. 